\title{
Intracranial pressure and venous sinus pressure gradients: what happens 3 months after stenting?
}

\author{
Hasan Asif, Claudia Craven", Syed N Shah, Simon D Thompson, Aswin Chari, Samir A Matloob, Neekhil A Patel, \\ Edward W Dyson, Patricia Haylock-Vize, Andrew R Stevens, Huan Wee Chan, Jinendra Ekanayake, Tarek Mostafa, \\ Ahmed K Toma, Laurence D Watkins
}

From Hydrocephalus 2015

Banff, Canada. 18-21 September 2015

\section{Introduction}

Benign Intracranial hypertension (BIH) is commonly associated with venous sinus stenosis. Increasingly, this is treated endovascularly with stent insertion. However, this treatment modality is still controversial. Clinical improvement post stent insertion has been described. Little is known about long-term control of intracranial pressure (ICP). In our unit, catheter cerebral venogram with pressure measurements is routinely performed 3 months post stent insertion in BIH patients. We aim to quantify the degree of venous pressure changes in stenosis patients treated with sinus stenting and how the changes correlate with radiographic improvements.

\section{Methods}

Single Centre case series. Clinical, angiographic and intracranial pressure data before and 3 months after stent placement were reviewed. All venograms were done under local anesthetic in supine position.

\section{Results}

Between 2011 and 2015, 33 patients underwent post stent insertion cerebral venogram as a routine follow up. Mean pre-stent superior sagittal sinus pressure was $28.8 \pm$ $2.0 \mathrm{mmHg}$ (mean \pm SEM). Mean 3 -months post-stenting superior sagittal sinus pressure was $10.5 \pm 0.7 \mathrm{mmHg}$ $(\mathrm{p}<0.0001)$. Pre-stenting pressure gradients across stenosis were reduced from $18.3 \pm 11.9 \mathrm{mmHg}$ to $6.3 \pm 4.5 \mathrm{mmHg}$ 3 -months post-stenting ( $\mathrm{p}<0.0001) .25$ of the 33 patients showed radiological stent patency and stenosis obliteration. Five developed new focal narrowing distal and three proximal to the stent.

* Correspondence: claudia.craven@gmail.com

Victor Horsley Department of Neurosurgery, National Hospital for Neurology \& Neurosurgery, Queen Square, London, UK

\section{Conclusions}

This study provides objective evidence of the effectiveness of venous sinus stent insertion in reducing intracranial pressure 3 months post procedure in the majority of patients with intracranial hypertension and focal venous sinus stenosis. Angiographic evidence of patent sinuses correlated with reduction in pressure gradients.

Published: 18 September 2015

doi:10.1186/2045-8118-12-S1-065

Cite this article as: Asif et al:: Intracranial pressure and venous sinus pressure gradients: what happens 3 months after stenting? Fluids and Barriers of the CNS 2015 12(Suppl 1):065.

\footnotetext{
Submit your next manuscript to BioMed Central and take full advantage of:

- Convenient online submission

- Thorough peer review

- No space constraints or color figure charges

- Immediate publication on acceptance

- Inclusion in PubMed, CAS, Scopus and Google Scholar

- Research which is freely available for redistribution

C Biomed Central

(C) 2015 Asif et al. This is an Open Access article distributed under the terms of the Creative Commons Attribution License (http:// creativecommons.org/licenses/by/4.0), which permits unrestricted use, distribution, and reproduction in any medium, provided the original work is properly cited. The Creative Commons Public Domain Dedication waiver (http://creativecommons.org/publicdomain/ zero/1.0/) applies to the data made available in this article, unless otherwise stated. 